\title{
TRADITIONAL AND TRANSGENIC STRATEGIES FOR CONTROLLING TOMATO-INFECTING BEGOMOVIRUSES*
}

\author{
JULIANA FREITAS-ASTÚA ${ }^{1 * *}$, DAN E. PURCIFULL ${ }^{2}$, \\ JANE E. POLSTON ${ }^{3} \&$ ERNEST HIEBERT ${ }^{2}$
}

${ }^{1}$ Empresa Brasileira de Pesquisa Agropecuária, Centro Apta Citros 'Sylvio Moreira', Rod. Anhanguera, km 158, Cx. Postal 4, 13490-970, Cordeirópolis, SP, Brazil, e-mail: jfastua@centrodecitricultura.br; ${ }^{2}$ University of Florida, Plant Pathology

Department, 1453 Fifield Hall, Gainesville, FL, USA, 32611, e-mails: depurc@aol.com, ehi@mail.ifas.ufl.edu; ${ }^{3}$ University of Florida, Gulf Coast Res. \& Educ. Ctr., $500760^{\text {th }}$ St. East, Bradenton, FL, USA, 34203, e-mail: jep@mail.ifas.ufl.edu

(Accepted for publication on 06/09/2002)

Author for correspondence: Juliana Freitas-Astúa

FREITAS-ASTÚA, J., PURCIFULL, D.E., POLSTON, J.E. \& HIEBERT, E. Traditional and transgenic strategies for controlling tomatoinfecting begomoviruses. Fitopatologia Brasileira 27:437-449. 2002.

\begin{abstract}
Viruses of to the family Geminiviridae are considered some of the most important pathogens in tropical and subtropical regions of the world. Members of one Geminiviridae genus, Begomovirus, have been causing severe losses, particularly in tomato (Lycopersicon esculentum) production in the Americas and the Caribbean. Several new begomoviruses have been reported in the region and, at least one, Tomato yellow leaf curl virus (TYLCV), has been brought in from the Old World via infected transplants. In addition, the recombination events that are playing an important role in

Begomovirus diversity have increased the complexity of their control. This scenario has led to the search for control measures that go beyond traditional host genetic resistance, chemical controls and cultural practices. In this review, besides the recommended classical control measures, transgenic approaches will be discussed, as well as the mechanisms involved in their successful control of viruses.

Additional key words: whitefly-transmitted geminivirus, gene silencing, plant transformation, tomato begomovirus, geminivirus control, Geminiviridae.
\end{abstract}

\section{RESUMO}

Estratégias tradicionais e transgênicas para o controle de begomovirus que infetam tomateiro

Membros do gênero Begomovirus, família Geminiviridae, estão entre os vírus mais importantes que infetam plantas nas regiões tropicais e subtropicais do mundo. Nas Américas, begomovirus vêm causando danos significativos especialmente para a produção de tomates (Lycopersicon esculentum). Inúmeros novos vírus têm sido relatados na região, e ao menos um, o Tomato yellow leaf curl virus (TYLCV), foi introduzido do Velho Continente através de plântulas infetadas. Além disso, recombinação aparentemente é um fator importante contribuindo para uma maior diversidade desses vírus, dificultando seu controle. Esta situação levou à procura de medidas de controle que vão além das normalmente utilizadas como resistência genética, controle químico e cultural. Nesta revisão, além de medidas tradicionais de controle de begomovirus, são discutidas principalmente estratégias de controle alternativas, como a utilização de plantas transgênicas, assim como os mecanismos envolvidos em tais estratégias

\section{BRIEF HISTORY AND TAXONOMY OF GEMINIVIRUSES}

Symptoms now known to be associated with geminiviruses have been observed in plants grown in tropical and subtropical regions of the world since the mid-1800s (Wege et al., 2000). However, it was not until the 1970s that a distinct group of single-stranded DNA (ssDNA) viruses was shown to be associated with such symptoms, and these were placed in the "Geminivirus" group (Gálvez \& Castaño, 1976; Goodman 1977a; 1977b; Harrison et al., 1977). Geminiviruses are characterized by the twinned, small (ca. 18-30 nm), quasiicosahedral morphology of the virion particles and by their

\footnotetext{
*Part of the Ph.D dissertation of the first author, University of Florida, USA ** CNPq fellowship
}

genomes consisting of one or two molecules of ssDNA 2.5$3.0 \mathrm{~kb}$ in length (Rybicki et al., 2000).

During the last decade, the geminiviruses were classified into the Geminiviridae family (Rybicki, 1994), which contains four genera: Mastrevirus, Curtovirus, Topocuvirus, and Begomovirus, classified according to their host range, genome organization, and vector species (Palmer \& Rybicki, 1998; Fauquet et al., 2000).

Members of the genus Begomovirus, such as the type species Bean golden yellow mosaic virus - Puerto Rico (BGYMV) [formerly named Bean golden mosaic virus (BGMV-PR) by Fauquet et al., 2000], are transmitted by the whitefly Bemisia tabaci Genn. in what is believed to be a persistent, circulative, non-propagative manner (Rybicki et al., 2000), although some authors have proposed otherwise (Mehta et al., 1994). Begomoviruses infect dicotyledonous 
plants and most have bipartite genomes, although some, such as, Tomato yellow leaf curl virus (TYLCV), have a single DNA component.

As there are already some recent reviews on geminivirus genome organization and replication (Castellano et al., 1999; Hanley-Bowdoin et al., 1999; Faria \& Zerbini, 2000; Gutierrez, 2000), as well as their interference with host cell cycle and gene expression (Gutierrez, 1998; 2000; Kong et al., 2000; Settlage et al., 2001), these topics will not be addressed in this review.

\section{IMPORTANCE OF GEMINIVIRUSES}

The Geminiviridae family has received a great deal of attention in recent years and is becoming one of the most important and studied families of plant virus. Some reasons why so much effort has been dedicated to their study include the economic and social impact of the diseases they cause (Palmer \& Rybicki, 1998; Harrison \& Robinson, 1999; Morales \& Anderson, 2001); their use as episomal vectors and gene silencing inducers (Hayes et al., 1988; Shen \& Hohn, 1995; Atkinson et al., 1998; Kjemtrup et al., 1998); and their contribution as models for studying intracellular and intercellular movement strategies of macromolecules (Noueiry et al., 1994; Sanderfoot \& Lazarowitz, 1995; 1996; Sanderfoot et al., 1996; Rojas et al., 1998; Gutierrez, 1999; Lazarowitz, 1999; Ward \& Lazarowitz, 1999).

In addition, concern for this family has increased due to the emergence of new geminiviruses through recombination or pseudorecombination among strains and/or species in various crops; the role of the recently discovered satellitelike DNA- $\beta$ components; and findings regarding the integration of begomovirus sequences into the genome of plants such as Nicotiana species (Bejarano et al., 1996; Ashby et al., 1997; Zhou et al., 1997; Navas-Castillo et al., 2000; Saunders et al., 2000; Saunders et al., 2001; Harper et al., 2002; Mette et al., 2002; Ribeiro et al., 2002).

These findings indicate that recombination has contributed to the diversity of geminiviruses and therefore, to the emergence of new variants and species reported worldwide. In the particular case of tomato (Lycopersicon esculentum Mill.)-infecting begomoviruses, recombination is likely an important factor in their evolution, even in the short and medium term (Zhou et al., 1997; Navas-Castillo et al., 2000; Saunders et al., 2001; Ribeiro et al., 2002). In the 1970s, there were only three begomoviruses reported to infect tomatoes in the Americas. Less than 30 years later, at least 14 new begomoviruses have been found in tomatoes in the region (Polston \& Anderson, 1997; Morales \& Anderson, 2001), and this number could be significantly higher since at least eight new putative whitefly-transmitted geminivirus (WTG) species were reported recently to infect this solanaceous plant in Brazil alone (Faria et al., 2000; Ribeiro et al., 2001; 2002).

Besides the large number of viruses, the losses they cause in tomato crops are extensive and some of them, such as TYLCV, can cause total yield loss (Czosnek \& Laterrot, 1997). Morales \& Anderson (2001) stated that the introduction of TYLCV to the Dominican Republic was the greatest tragedy in the history of WTG affecting economically important crops in the Caribbean, and caused the collapse of the tomato industry in that country.

\section{TRADITIONAL APPROACHES FOR CONTROLLING BEGOMOVIRUSES INFECTING TOMATOES}

As mentioned above, there are several reasons why geminiviruses are studied worldwide. Their main importance, however, is related to their ability to cause significant yield losses to numerous crops. Several approaches have been used in attempts to control begomoviruses infecting tomato plants, but only a few of them have proven to be effective. There is a possibility of controlling $B$. tabaci biologically, but it has not been used for tomato production since the results are very unsatisfactory (Mason et al., 2000). Additional information on the current situation, problems, and the potential use of fungi and predators or parasitoids to control whiteflies can be found in reviews by Faria \& Wraight (2001) and Gerling et al. (2001), respectively.

Cultural practices such as roguing, intercropping, avoidance, use of barriers, crop residue disposal, among others, are recommended, but they should be combined with the use of insecticides and/or resistant varieties in order to be effective, especially in tropical areas, where tomato production occurs throughout the year (Polston \& Anderson, 1997; Villas Bôas et al., 1997; Faria et al., 2000; Hilje et al., 2001). Reductions in the incidence of TYLCV (Cohen, 1982; Suwwan et al., 1988) and Tomato mottle virus (ToMoV) (Csizinszky et al., 1995) in tomatoes were observed with different levels of efficiency when yellow or orange polyethylene films and aluminum mulches were used. However, despite of some positive results, the use of mulches is not always practical and cost-effective, especially when tomatoes are grown in large areas.

The best results of WTG cultural control in tomatoes reported to date seem to occur when ultraviolet-absorbing plastic films are used as greenhouse covers or as insect-proof nets (Antignus et al., 1998; Antignus, 2000). Besides being a physical barrier for the insects, these UV-absorbing films can reduce virus incidence through the inhibition of whitefly movement, and have proven especially efficient for the control of begomoviruses. Antignus et al. (1996) demonstrated that TYLCV incidence in tomato plants grown under the UVabsorbing sheets was only $1 \%$ compared with approximately $80 \%$ in the uncovered control. Because of its high efficacy, the use of screens has become a standard pest management strategy for the production of tomatoes in Israel (Taylor et $a l ., 2001)$. It is important to note, however, that besides the higher production cost, these screens alone may not sufficiently protect against TYLCV, and their use may result in increased temperature and humidity inside greenhouses 
(Mason et al., 2000; Moriones \& Navas-Castillo, 2000).

Although the elimination of alternative hosts is often recommended for reduction of viruses in general, weeds are not normally considered to be important reservoirs of tomatoinfecting begomoviruses under natural conditions (Polston \& Anderson, 1997; Ucko et al., 1998; Moriones \& NavasCastillo, 2000). Some exceptions include the relevance of few weeds in the TYLCV epidemics in the Jordan Valley, Israel (Cohen et al., 1988) and the possibility of their contribution to WTG variability in the tropics. The most important aspect of removing weeds around tomato fields, however, has been considered to be the likelihood of diminishing the vector population. Whiteflies, particularly the B. tabaci biotype B, are polyphagous and have been reported in at least 506 species within 74 plant families of dicots and monocots (Villas Bôas et al., 1997; Chatterji \& Fauquet, 2000). However, Hilje et al. (2001) suggest that it may not be worthwhile to spend resources on weed removal for the control of the New World begomoviruses. In addition, weeds also serve an important function as reservoirs of whitefly predators, parasites and pathogens.

Regulatory measures have also been taken in a few instances. A mandatory three-month tomato-free period from June through August has been issued in the Dominican Republic and has helped to drastically reduce the incidence of TYLCV in the first half of the growing season. By the end of the season, however, high incidences of the virus can be seen in the fields, and losses can be significant if TYLCVsusceptible cultivars are planted (Polston \& Anderson, 1997; Salati et al., 1999).

The use of resistant tomato plants is undoubtedly the best way to control begomoviruses (Polston \& Anderson, 1997; Mason et al., 2000). A great effort has been made to obtain genetic resistance to begomoviruses, with much of it directed against TYLCV. Several groups of researchers have looked for TYLCV resistance and tolerance among wild Lycopersicon species and have found some promising materials within L. chilense Dun., L. pimpinellifolium (Jusl.) Mill., L. hirsutum Dun., L. cheesmani Riley, and L. peruvianum (L.) Mill. (Kasrawi et al., 1988; Zakay et al., 1991; Michelson et al., 1994; Picó et al.; 1998; Vidavsky \& Czosnek, 1998, among others). Some accessions of tomato wild relatives exhibited good levels of resistance and tolerance to bipartite begomovirus as well, such as Tomato yellow mosaic virus (Piven \& Uzcátegui, 1995) and the $\mathrm{DF}_{1}$ isolate (Ferreira et al., 1999; Santana et al., 2001).

Besides the direct genetic resistance to begomoviruses, resistance to the whitefly vector has been reported in some wild Lycopersicon species, such as L. hirsutum and L. peruvianum (Morales, 2001). It has been associated with the large amounts of sticky substances that plants of these species exudate, entrapping the whiteflies and significantly reducing the transmission of begomoviruses (Channarayappa \& Shivashankar, 1992; Morales, 2001). Unfortunately, this is not a desired trait for commercial tomato plants.

With such a broad range of tolerance and resistance in nature, only a few breeding lines and varieties have been produced (Rom et al., 1993; Lapidot et al., 1997; Mason et $a l ., 2000)$. However, in commercial fields of most regions of the world, tomato plants are still largely susceptible to various begomoviruses (Polston \& Anderson, 1997; Mason et al., 2000; Diaz-Plaza et al., 2001). In addition, it is a concern that some asymptomatic, tolerant cultivars support the replication of the virus, and can act as sources of begomovirus for susceptible crops (Lapidot et al., 2001).

Liu \& Stansly (2000) have tested several surfactants and oils against whitefly nymphs on tomato plants. Although there were good levels of insect mortality in some cases, phytotoxicity was observed in many instances. Their effects on yields were not reported.

Ultimately, the management of begomoviruses infecting tomatoes relies heavily on the use of a combination of systemic and topical insecticides to control the vector (Polston \& Anderson, 1997; Villas Bôas et al., 1997; Faria et al., 2000; Mason et al., 2000; Ahmed et al., 2001). However, although effective for some time, there are some concerns about chemical controls. In Honduras, there were outbreaks of secondary pests such as leafminers due to the repetitive use of insecticides to control whiteflies (Rafie et al., 1999). Cahill et al. (1996) reported the development of whiteflies resistant to imidacloprid in Spain. This observation is of major concern because this active ingredient is the most important insecticide used to control whiteflies and thus, begomoviruses (Cahill et al., 1996; Polston \& Anderson, 1997; Ahmed et al., 2001).

This scenario, associated with increasing concerns for obtaining more environmentally friendly ways to control pests and diseases, has encouraged a search for alternatives to control begomoviruses in tomatoes, especially through transgenic approaches. The strategies used by various research groups and the results obtained so far will be discussed after a brief review of the mechanisms involved in transgenic resistance against plant viruses.

\section{MECHANISMS OF GENETIC ENGINEERING FOR PLANT VIRUS RESISTANCE}

\section{The Concept of Pathogen-Derived Resistance (PDR)}

Sanford \& Johnson (1985), working with bacteriophages, described the concept of pathogen-derived resistance (PDR), which can be used in plant virology. It can be defined as the transformation of plants with portions of viral genomes that can generate lines of plants resistant to the virus from which the sequence was derived. Only one year after Sanford and Johnson's publication, Powell-Abel et al. (1986) reported that tobacco (Nicotiana tabacum L.) plants transformed with the capsid protein $(C P)$ gene of Tobacco mosaic virus (TMV) genus Tobamovirus were resistant to infection by TMV.

Since then, numerous papers and reviews have been published on PDR, and the concept has been proven valid for a wide variety of plants, for a number of genes or portions of 


\section{J. Freitas-Astúa et al.}

genes, and for members of virtually every genus of plant viruses.

Several researchers classify PDR based on the open reading frame (ORF) used for transformation or its product. In this review we briefly describe what we consider to be the three major groups within PDR, regardless of the viral sequence that led to resistance. It is important to note that so far these concepts have been accepted for RNA viruses, but not yet proven for DNA viruses. However, the observations suggest that the mechanisms involved in resistance are similar for both RNA and DNA viruses.

\section{Protein-Mediated Resistance}

Early experiments demonstrated that plants transformed with the $C P$ gene of TMV were more resistant when high levels of the viral capsid protein were expressed, confirming the importance of the actual protein in resistance (Powell-Abel et al., 1986). Because of that, it was named protein-mediated resistance (PMR) or, in this particular case, coat protein-mediated resistance (CPMR). Other characteristics associated with PMR are that the resistance is normally broken down or reduced when the inoculum is nucleic acid rather than intact virions, it is often manifested as a delay in the appearance of symptoms, it is normally partial but broad-spectrum, and it is dependent on inoculum concentrations and environmental conditions (Powell-Abel et al., 1986; Nejidat \& Beachy, 1989; Pappu et al., 1995; Baulcombe, 1996).

At least for plants transformed with the TMV CP gene, the formulated hypothesis to explain resistance is that it occurs by the inhibition of challenge virion disassembly in the initial infected cells (Bendahmane et al., 1997). Interestingly, this agrees with the concept of cross protection, defined as the ability of one virus to inhibit or prevent infection or the manifestation of a closely related second virus (Dodds, 1982). Yet, another similarity between CPMR and cross protection is that, in both cases, unencapsidated viral RNA can overcome the resistance suggesting that the protective virus in cross protection blocks the disassembly of the challenge virus as well (Sherwood \& Fulton, 1982; Register \& Beachy, 1988).

Similarly to what was described for the CPMR, movement protein-mediated resistance (MPMR) has often been associated with high levels of protein production by transgenic plants, but only when dysfunctional, rather than full-length MP, is expressed (Ziegler-Graff et al., 1991; Lapidot et al., 1993; Beck et al., 1994; Cooper et al., 1995).

It is thought that the resistance obtained in plants transformed with a dysfunctional TMV MP gene occurs due to competition for plasmodesmatal binding sites between the mutant MP and the wild-type MP of the inoculated virus (Lapidot et al., 1993). Some examples of the broad-spectrum MPMR suggest that different virus movement proteins interact with the same plasmodesmatal components (Baulcombe, 1996), likely pectin methyl esterase (Chen et al., 2000). Lapidot et al. (1993) observed a correlation between the accumulation of a defective TMV MP and resistance to the viral infection. This is characteristic of a dominant negative mutation, defined as the ability of a mutant gene to code for a mutant product, which then inhibits the wild-type gene product in a cell, causing the cell to be deficient in the function of that gene product (Herskowitz, 1987).

It is important to note, however, that in many cases plants transformed with viral $C P$ or $M P$ genes (Lindbo \& Dougherty, 1992a; Van der Vlugt et al., 1992; Sijen et al., 1995, 1996; Prins et al., 1997; Sinisterra et al., 1999) do not produce the corresponding viral protein, and yet are resistant to the challenge homologous virus. These examples are normally associated with a different class of PDR, the RNAmediated resistance.

\section{RNA-Mediated Resistance and Post-Transcriptional Gene Silencing}

According to Prins \& Goldbach (1996), the RNAmediated resistance (RMR) approach arose as an unexpected spin off from the concept of PDR. In contrast to what was expected, the resistance observed in several transgenic lines, especially those transformed with the replicase gene (Rep) had no direct correlation with the levels of protein produced (Anderson et al., 1992; Audy et al., 1994; Baulcombe, 1994). In addition, in the early 1990s, several research groups reported that plants transformed with untranslatable sequences of viruses were resistant to their challenge homologous viruses (Lindbo \& Dougherty, 1992a, b; Van der Vlugt et al., 1992).

Lindbo et al. (1993) demonstrated through run-on analysis that tissues that exhibited a typical "recovery phenotype" (tissues that initially exhibited symptoms, but whose symptoms would disappear with time) had high levels of transcription of the transgenes in the nucleus and very low levels in the cytoplasm. These observations led them to propose the presence of an RNA-degradation mechanism, which would be activated by the presence of high levels of a specific transcript. Lindbo et al. (1993) also demonstrated that extensive methylation of the transgene sequence was likely associated with induction of the specific cytoplasmic RNA degradation mechanism. These observations were typical of gene silencing, which had been recently described in plants and was getting a great deal of attention (Napoli et al., 1990; Van der Krol et al., 1990). Since the degradation occurred after transcription took place, it was named posttranscription gene silencing (PTGS).

In addition to the recovery phenotype (that may or may not occur) and the failure to detect the product of the transgene due to mRNA degradation, there are other features normally associated with gene silencing. The RMR is often complete or almost complete (high levels of resistance or immunity), regardless of the inoculum concentration or environmental conditions, but it is specific to the virus from which the sequence was derived (low-spectrum resistance) (Lomonossoff, 1995).

In contrast to what was originally thought, gene silencing (GS) is not only induced by transgenes, but also by viruses carrying sequences with homology to host transgenes 
or endogenous genes (Lindbo et al., 1993; English et al., 1996). Since 1997, it has been noticed that GS has striking similarities with natural plant defense mechanisms against viruses and that plant virus infections in the absence of any known homology to host genes could also induce GS (Covey et al., 1997; Ratcliff et al., 1997; Al-Kaff et al., 1998; Covey \& Al-Kaff, 2000).

In 1998, four groups of researchers demonstrated, virtually at the same time, that PTGS is indeed a plant defense mechanism by showing that some viruses have a counterdefensive strategy involving the suppression of GS (Anandalakshmi et al., 1998; Beclin et al., 1998; Brigneti et al., 1998; Kasschau \& Carrington, 1998). This discovery provided some explanation to the phenomenon that had been heavily associated with transgenic plants, but that in reality, is normally targeted against naturally invading nucleic acids, particularly viruses and transposable elements (Smyth, 1999; Waterhouse et al., 2001).

The phenomenon of PTGS appears to be quite common in nature. With the exception of baker's yeast (Aravind et al., 2000), apparently all eukaryotes have mechanisms similar to gene silencing, often called RNA interference (RNAi). This demonstrates that organisms such as fungi (Cogoni et al., 1996; Cogoni \& Macino, 1997; Faugeron, 2000), protozoa (Ngo et al., 1998), a variety of animals (Fire et al., 1998; Lohmann et al., 1999; Sánchez-Alvarado \& Newmark, 1999; Wargelius et al., 1999; Cogoni \& Macino, 2000; Ketting \& Plasterk, 2000; Wianny \& Zernicka-Goetz, 2000; Elbashir et al., 2001) and plants have possibly a common ancestral origin (Cogoni \& Macino, 2000, Fagard et al., 2000; Zamore et al., 2000; Hammond et al., 2001a; Zamore, 2002).

In this review, the mechanisms involved in PTGS as well as the role of double-stranded (ds) RNA transcripts and small (s) RNA in GS will not be discussed since several reviews covering these aspects have already been written (Wassenegger \& Pélissier, 1998; Waterhouse et al., 1998; Bass, 2000; Marathe et al., 2000; Hammond et al., 2001b; Hutvágner et al., 2000; Zamore et al., 2000; Li \& Ding, 2001; Miller et al., 2001; Zamore, 2002).

Interestingly, it has been recently proposed that common processing machinery generates sRNAs that mediate both RNAi and endogenous gene regulation involved in development (Elbashir et al., 2001; Grishok et al., 2001; Hutvágner et al., 2001; Zamore, 2002). This suggests that PTGS might not only be a defense mechanism against viruses and transposable elements, but also might be part of a developmental regulation system (Hutvágner \& Zamore, 2002).

\section{RNA- and Protein-Mediated Resistance}

Some researchers have found yet more complex results in their studies on transgenic resistance. Pang et al. (1994) reported that the mechanisms involved in the $C P$ genemediated resistance against tospoviruses were variable. When the resistance was against closely related isolates, it was RNAmediated, but when it was against more distantly related tospoviruses, it was protein-mediated. Wintermantel \& Zaitlin (2000) suggested that, in tobacco plants transformed with the Cucumber mosaic virus (CMV) family Bromoviridae, genus Cucumovirus replicase gene, the resistance obtained is likely a result of a complex mechanism involving both transgene mRNA and its expressed protein.

Recently, Goregaoker et al. (2000) demonstrated that in TMV replicase-mediated resistance, both RNA and protein are involved in protecting against the challenge virus. Interestingly, over the years many authors have reported divergent conclusions regarding the mechanism involved in the resistance of plants transformed with the TMV $R d R p$ gene. In some cases, the resistance seemed to be mediated by the RNA transcripts (Tenllado et al., 1996; Marano \& Baulcombe, 1998), while in others, it seemed to be proteinmediated (Carr et al., 1992; Donson et al., 1993).

Finally, Goregaoker et al. (2000) propose that the protection conferred by segments of the TMV $R d R p$ gene expressed from a heterologous viral vector can be credited to the $R d R p$ mRNA and also to the protein expression from segments of the polymerase (POL) domain, the latter conferring greater delays in the accumulation of challenge TMV when compared to the RNA-mediated mechanism. The authors further propose that both mechanisms possibly work cooperatively, with the protein-mediated mechanism functioning to slow down wild-type virus replication to a level that allows the RNA-mediated mechanism to be more effective (Goregaoker et al., 2000).

\section{Nonpathogen-Derived Approaches}

Although most of the transgenic resistance to viruses has been obtained by PDR, there are some cases where it can be achieved through nonpathogen-derived approaches. The ribosome-inactivating proteins (RIPs), such as dianthin extracted from Dianthus caryophyllus L., have natural control effects against several plant and animal viruses. Although their use for genetic engineering has not been reported for any tomato-infecting begomovirus so far, the dianthin gene, under the control of the African cassava mosaic virus (ACMV) family Geminiviridae, genus Begomovirus promoter, has been used successfully to confer resistance in N. benthamiana Domin against this WTG (Hong et al., 1996; Hong \& Stanley, 1996).

To our knowledge, other nonpathogen-derived strategies such as the expression of antiviral proteins (i.e. ribozymes), ribonucleases, and antibodies, have not yet been reported as alternative methods to control begomoviruses, and will not be addressed in this review.

\section{TRANSGENIC APPROACHES USED FOR CONTROLLING BEGOMOVIRUSES INFECTING TOMATO PLANTS}

As previously mentioned, most of what is known about PDR derives from plants transformed with RNA viral sequences, but an increasing number of papers have been 


\section{J. Freitas-Astúa et al.}

published on transgenic resistance for DNA viruses as well.

Of the 104 begomoviruses characterized to date, approximately 30 are reported as pathogens of tomato (Fauquet et al., 2000). However, transgenic approaches have been used so far in attempts to control only a few of them, mainly ToMoV, TYLCV, Tomato yellow leaf curl Sardinia virus (TYLCSV), Tomato golden mosaic virus (TGMV), and Pepper huasteco virus (PHV). Most of the effort has been directed toward the control of TYLCV and TYLCSV, which are considered the most important tomato-infecting begomoviruses in several countries. However, most of those studies have been carried out on $N$. tabacum or $N$. benthamiana plants, and only a few transgenic tomato lines have been produced that are resistant to WTGs.

Several viral sequences have been used in attempts to obtain plants resistant to tomato-infecting begomoviruses, with results that vary from immunity to complete susceptibility. The CP genes of TYLCV and ToMoV were used, respectively, by Kunik et al. (1994) to transform tomato and by Sinisterra et al. (1999) to transform tobacco plants. Although in the first case the authors used the full-length of the $C P$ gene and in the latter, a truncated $C P$ gene (with a deletion of 30 nucleotides at the 5 'end), both studies reported resistance to challenge TYLCV and ToMoV, respectively. However, while the resistance reported by Kunik et al. (1994) was expressed as a delay in symptoms, recovery phenotype, and was associated with high levels of expressed CP protein, Sinisterra et al. (1999) observed higher levels of resistance and suggested that it was mediated by the RNA transcripts. Unfortunately, Sinisterra et al. (1999) noticed that the progeny from plants that were resistant in the $\mathrm{R}_{1}$ generation were susceptible to ToMoV in the $\mathrm{R}_{2}$, and Kunik et al. (1994) did not seem to have carried out the experiments to further generations.

Resistance was also observed in tobacco plants transformed with antisense sequences of the $C P$ gene plus the $5^{\prime}$ portion of the transcription activator $(\operatorname{Tr} A P)$ and replication enhancer (REn) genes of TGMV (Bejarano \& Lichtenstein, 1994). In this case, transgenic plants were asymptomatic after inoculation with the challenge virus, probably due to a drastic impairment in its replication (Bejarano \& Lichtenstein, 1994).

The cell-to-cell movement and the nuclear shuttle protein genes ( $M P$ and NSP, respectively) also have been used to confer resistance to begomoviruses. The ToMoV and Bean dwarf mosaic virus (BDMV) MP and NSP genes have been used to transform tobacco and tomato by Duan et al. (1997) and Hou et al. (2000), respectively. Some resistance to ToMoV was obtained for constructs containing the $M P$ sequence in the first case, and for NSP and MP constructs in the latter study. However, even though it appears that the expression of the protein is involved in the resistance, this was not clearly demonstrated. Besides, the resistance obtained by Hou et al. (2000) was expressed as only a delay in the appearance of the ToMoV symptoms.

A recent report demonstrated that tobacco plants transformed with ToMoV MP gene behaved biologically as if the resistance was RNA-mediated (recovery phenotype, high levels of narrow-range resistance, independent of levels of inoculum, and even after challenge with viral DNA through biolistic inoculation), but exhibited some characteristics at the molecular level that are typical of protein-mediated resistance (low, but detectable levels of MP mRNA and protein after challenge with ToMoV) (Freitas-Astúa, 2001; FreitasAstúa et al., 2001a). The use of antisense sequences of ToMoV NSP and MP did not confer resistance to tobacco plants (Duan et al., 1997; Freitas-Astúa et al., unpublished data).

Another gene often used for obtaining transgenic resistance to tomato-infecting begomoviruses is the replication-associated (Rep) gene. Noris et al. (1996) were the first to demonstrate that the expression of a truncated TYLCSV Rep, encoding the first 210 amino acids of the Rep protein and potentially co-expressing the $\mathrm{C} 4$ protein, could confer high levels of resistance in $N$. benthamiana plants. However, resistance was overcome with time. This truncated gene was also used to transform tomato plants (Brunetti et al., 1997). Transformed plants that expressed high levels of the truncated TYLCSV Rep protein were resistant to TYLCSV infection, whereas those tomato lines in which the protein was not expressed (lines containing the antisense Rep or both sense and antisense Rep gene) were susceptible to TYLCSV. However, resistant plants exhibited an undesired, altered phenotype, and the resistance did not seem to be effective against a different begomovirus, Tomato leaf curl - Australia virus (Brunetti et al., 1997). Further studies of the same research group demonstrated that $N$. benthamiana plants expressing the truncated Rep of TYLCSV were resistant to the homologous virus, but susceptible to the related TYLCV Murcia strain (TYLCV-ES[1]). According to the authors, the truncated Rep acts as a trans-dominant-negative mutant inhibiting transcription and replication of TYLCSV, but not of TYLCV-ES[1] (Brunetti et al., 2001).

Day et al. (1991) reported the production of resistant tobacco plants expressing an antisense sequence of the TGMV Rep gene in the $\mathrm{R}_{1}$ generation; however, the studies did not continue on further generations. Bendahmane \& Gronenborn (1997) demonstrated that the use of the full-length antisense Rep conferred moderate resistance to TYLCSV in $N$. benthamiana, and this resistance was inherited in the $\mathrm{R}_{2}$ generation as well. Interestingly, in both cases the level of homology between the antisense RNA and the challenge virus sequence specified the level of resistance obtained.

Recently, Franco et al. (2001) have shown resistance of $N$. benthamiana to TYLCSV by a double mechanism involving antisense RNA of TYLCSV Rep gene and extrachromosomal molecules; however, the plants were not protected against TYLCV, which is a more severe virus.

As it can be clearly seen, most studies on transgenic plants expressing the Rep gene or its antisense RNA were done on $N$. benthamiana, a known permissive host. There are a few exceptions to that, though. Polston \& Hiebert (personal communication) used the full length ToMoV Rep 
gene to obtain tomato plants resistant to ToMoV. Stout et al. (1997), based on the work by Hanson et al. (1995), who demonstrated that the NTP-binding domain of BGYMV is required for replication, mutated this motif in ToMoV, transformed tomato plants with such construct, and showed that it interferes with ToMoV replication.

Even though some tomato lines are resistant to ToMoV, until recently there were no reports of transgenic tomato plants satisfactorily resistant to TYLCV, a virus that is considered the most important begomovirus infecting tomatoes, both for its wide geographical distribution and for the severe losses it can cause. Only a short time ago, a construct consisting of 2/ 5 of the TYLCV Rep gene was demonstrated to confer high levels of resistance and often immunity to TYLCV in both tobacco and tomato, probably through the mechanism of PTGS (Freitas-Astúa et al., 2001b; Polston et al., 2001). The relevance of these studies is based on the fact that several lines of transformed tomato and tobacco plants were immune to TYLCV in the $R_{1}$ and $R_{2}$ generations, and that similar responses were observed in two different hosts, in independent transformations. These results suggest that the $2 / 5$ TYLCV Rep construct is a strong gene silencing inducer (Polston, personal communication).

However, since numerous viruses can infect tomatoes, often in mixed infections, it is imperative that in some regions of the world the resistant plants exhibit broad-spectrum resistance. For that reason, new strategies are leading towards gene pyramiding or crossing of material already resistant to one virus with lines resistant to other viruses, or the use of negative dominant mutants that can confer good levels of resistance not only to the virus from which the sequence was derived, but also to related viruses (such as recombinants and variants or even other begomovirus species).

Diaz-Plaza et al. (2001) reported that tobacco plants expressing mutated PHV MP gene were resistant to the homologous virus and also exhibited some resistance to Texas pepper virus (TPV) family Geminiviridae, genus Begomovirus, probably through negative dominance. The authors have transformed tomatoes with the same mutated PHV MP gene, but the plants have not yet been tested (DiazPlaza \& Rivera-Bustamante, personal communication). However, it is expected that the same construct would provide similar broad-spectrum resistance in another solanaceous host, such as tomato plants.

Chatterji et al. (2001) have recently shown that the transient expression of the Tomato leaf curl New Delhi virus (ToLCNDV) family Geminiviridae, genus Begomovirus, Rep protein, mutated at the oligomerization and DNA binding domains, inhibits viral DNA accumulation in tobacco protoplasts and in $N$. benthamiana plants. Interestingly, in vivo experiments of co-bombardment of this construct with infectious clones of ACMV, PHV, or Potato yellow mosaic virus (PYMV) in $N$. benthamiana suggest that the mutated protein might interfere, at different levels, not only with the homologous ToLCNDV, but with these other begomoviruses as well (Chatterji et al., 2001). These results are also promising, and transgenic tobacco and tomato plants are being tested for resistance to begomoviruses (Chatterji et al., 2001).

Finally, a new possibility for broad-spectrum resistance for begomoviruses relies on a recent study done by ArgüelloAstorga \& Ruiz-Medrano (2001). The authors found similarities among iterons (high affinity binding sites for the Rep protein, functioning as origin recognition sites) of more than 100 geminiviruses and proposed that the common specificities of the Rep-iteron interactions might be used in developing Rep-based virus resistance to a range of geminiviruses with similar interaction specificities.

\section{FINAL REMARKS}

Only time will tell if strategies chosen today will actively help control tomato-infecting begomoviruses or if new approaches will need to be pursued. However, although no begomovirus-resistant transgenic tomato plants are yet available to growers, some of these lines are very promising and might in the near future be cultivated or used in breeding programs.

\section{ACKNOWLEDGMENTS}

The authors would like to thank Drs. Josias C. Faria (Embrapa Arroz e Feijão) and Gustavo Astúa-Monge (Centro Apta Citros "Sylvio Moreira"/IAC) for critically reviewing the manuscript.

\section{LITERATURE CITED}

AHMED, N.E., KANAN, H.O., SUGIMOTO, Y., MA, Y.Q. \& INANAGA, S. Effect of imidacloprid on incidence of Tomato yellow leaf curl virus. Plant Disease 85:84-87. 2001.

AL-KAFF, N.S., COVEY, S.N., KREIKE, N.M., PAGE, A.M. \& DALE, P.J. Transcriptional and post-transcriptional gene silencing in response to a pathogen. Science 279:2113-2115. 1998.

ANANDALAKSHMI, R., PRUSS, G.J., GE, X., MARATHE, R., MALLORY, A., SMITH, T.H. \& VANCE, V.B. A viral suppressor of gene silencing in plants. Proceedings of the National Academy of Sciences of the USA 95:13079-13084. 1998.

ANDERSON, J.M., PALUKAITIS, P. \& ZAITLIN, M. A defective replicase gene induces resistance to cucumber mosaic virus in transgenic tobacco plants. Proceedings of the National Academy of Sciences of the USA 89:8759-8763. 1992.

ANTIGNUS, Y. Manipulation of wavelength-dependent behaviour of insects: an IPM tool to impede insects and restrict epidemics of insect-borne viruses. Virus Research 71:213-220. 2000.

ANTIGNUS, Y., LAPIDOT, M., HADAR, D., MESSIKA, Y. \& COHEN, S. Ultraviolet-absorbing screens serve as optical barriers to protect crops from virus and insect pests. Journal of Economic Entomology 91:1401-1405. 1998.

ANTIGNUS, Y., MOR, N., BEN-JOSEPH, R., LAPIDOT, M. \& COHEN, S. UV-absorbing plastic sheets protect crops from insect pests and from virus diseases vectored by insects. Environmental Entomology 25:919-924. 1996.

ARAVIND, L., WATANABE, H., LIPMAN, D.J. \& KOONIN, E.V. 


\section{J. Freitas-Astúa et al.}

Lineage-specific loss and divergence of functionally linked genes in eukaryotes. Proceedings of the National Academy of Sciences of the USA 97:11319-11324. 2000.

ARGÜELLO-ASTORGA, G.R. \& RUIZ-MEDRANO, R. An iteronrelated domain is associated to motif 1 in the replication proteins of geminiviruses: Identification of potential interacting amino acid-based pairs by a comparative approach. Archives of Virology 146:1465-1485. 2001.

ASHBY, M.K., WARRY, A., BEJARANO, E.R., KHASHOGGI, A., BURRELL, M. \& LICHTENSTEIN, C.P. Analysis of multiple copies of geminiviral DNA in the genome of four closely related Nicotiana species suggests a unique integration event. Plant Molecular Biology 35:313-321. 1997.

ATKINSON, R.G., BIELESKI, L.R., GLEAVE, A.P., JANSSEN, B. $\&$ MORRIS, B.A.M. Post-transcriptional silencing of chalcone synthetase in petunia using a geminivirus-based episomal vector. Plant Journal 15:593-604. 1998.

AUDY, P. PALUKAITIS, P., SLACK, S.A. \& ZAITLIN, M. Replicase mediated resistance to potato virus $\mathrm{Y}$ in transgenic plants. Molecular Plant-Microbe Interactions 7:15-22. 1994.

BASS, B.L. Double stranded RNA as a template for gene silencing. Cell 101:235-238. 2000.

BAULCOMBE, D.C. Replicase-mediated resistance: a novel type of virus resistance in transgenic plants. Trends in Microbiology 2:60-63. 1994.

BAULCOMBE, D.C. Mechanisms of pathogen-derived resistance to viruses in transgenic plants. Plant Cell 8:1833-1844. 1996.

BECK, D.L., VAN DOLLEWEERD, C.J., LOUGH, T.L., BALMORI, E., VOOT, D.M., ANDERSEN, M.T., O'BRIEN, I.E.W. \& FORSTER, R.L. Disruption of virus movement confers broad-spectrum resistance against systemic infection by plant viruses with a triple gene block. Proceedings of the National Academy of Sciences of the USA 91:10310-10314. 1994.

BECLIN, C., BERTHOME, R., PALAUQUI, J.C., TEPFER, M. \& VAUCHERET, H. Infection of tobacco or Arabidopsis plants by CMV counteracts systemic post-transcriptional silencing of non-viral (trans)genes. Virology 252:313-317. 1998.

BEJARANO, E.R., KHASHOGGI, A., WITTY, M. \& LICHTENSTEIN, C.P. Integration of multiple repeats of geminiviral DNA into the nuclear genome of tobacco during evolution. Proceedings of the National Academy of Sciences of the USA 93:759-764. 1996.

BEJARANO, E.R. \& LICHTENSTEIN, C.P. Expression of TGMV antisense RNA in transgenic tobacco inhibits replication of BCTV but not ACMV geminiviruses. Plant Molecular Biology 24:241-248. 1994.

BENDAHMANE, M., FITCHEN, J.H., ZHANG, G. \& BEACHY, R.N. Studies of coat protein-mediated resistance to tobacco mosaic tobamovirus: Correlation between assembly of mutant coat proteins and resistance. Journal of Virology 71:7942-7950. 1997.

BENDAHMANE, M. \& GRONENBORN, B. Engineering resistance against tomato yellow leaf curl virus using antisense RNA. Plant Molecular Biology 33:351-357. 1997.

BRIGNETI, G., VOINNET, O., WAN-XIANG, L., LIANG-HUI, J., DING, S.W. \& BAULCOMBE, D.C. Viral pathogenicity determinants are suppressors of transgene silencing in Nicotiana benthamiana. EMBO Journal 17:6739-6746. 1998.

BRUNETTI, A., TAVAZZA, M., NORIS, E., TAVAZZA, R., CACIAGLI, P., ANCORA, G., CRESPI, S. \& ACCOTTO, G.P. High expression of truncated viral Rep protein confers resistance to tomato yellow leaf curl virus in transgenic tomato plants. Molecular Plant-Microbe Interactions 10:571-579. 1997.

BRUNETTI, A., TAVAZZA, R., NORIS, E., LUCIOLI, A., ACCOTTO, G.P \& TAVAZZA, M. Transgenically expressed T-Rep of Tomato yellow leaf curl Sardinia virus acts as a transdominant-negative mutant, inhibiting viral transcription and replication. Journal of Virology 75:10573-10581. 2001.

CAHILL, M., GORMAN, K., KAY, S. \& DENHOLM, I. Baseline determination and detection of resistance to imidacloprid in Bemisia tabaci (Homoptera:Aleyrodidae). Bulletin of Entomological Research 86:343-349. 1996.

CARR, J.P., MARSH, L.E., LOMONOSSOFF, G.P., SEKIYA, M.E. $\&$ ZAITLIN, M. Resistance to tobacco mosaic virus induced by the $54-\mathrm{kDa}$ gene sequence requires expression of the 54$\mathrm{kDa}$ protein. Molecular Plant-Microbe Interactions 5:397-404. 1992.

CASTELLANO, M.M., SANZ-BURGOS, A.P. \& GUTIERREZ, C. Initiation of DNA replication in a eukaryotic rolling-circle replicon: identification of multiple DNA-protein complexes at the geminivirus origin. Journal of Molecular Biology 290:639-652. 1999.

CHANNARAYAPPA, A. \& SHIVASHANKAR, G. Resistance of Lycopersicon species to Bemisia tabaci, a tomato leaf curl virus vector. Canadian Journal of Botany 70:2184-2192. 1992.

CHATTERJI, A., BEACHY, R.N. \& FAUQUET, C.M. Expression of the oligomerization domain of the replication-associated protein (Rep) of tomato leaf curl New Delhi virus interferes with DNA accumulation of heterologous geminiviruses. The Journal of Biological Chemistry 276:25631-25638. 2001.

CHATTERJI, A. \& FAUQUET, C.M. Ecology of plant viruses, with special reference to whitefly-transmitted geminiviruses (WTGs). In: Hurst, C.J. (Ed.) Viral Ecology. San Diego. Academic Press. 2000. pp. 321-352.

CHEN, M.-H., SHENG, J., HIND, G., HANDA, A.K. \& CITOVSKY, V. Interaction between the tobacco mosaic virus movement protein and host cell pectin methylesterases is required for viral cell-to-cell movement. EMBO Journal 19:913-920. 2000.

COGONI, C., IRELAN, J.T., SCHUMACHER, M., SCHMIDHAUSER, T.J., SELKER, E.U. \& MACINO, G. Transgene silencing of the al-1 gene in vegetative cells of Neurospora is mediated by a cytoplasmic effector and does not depend on DNA-DNA interactions or DNA methylation. EMBO Journal 15:3153-3163. 1996.

COGONI, C. \& MACINO, G. Isolation of quelling-defective (qde) mutants impaired in post-transcriptional transgene-induced gene silencing in Neurospora crassa. Proceedings of the National Academy of Sciences of the USA 94:10233-10238. 1997.

COGONI, C. \& MACINO, G. Post-transcriptional gene silencing across kingdoms. Current Opinion of Genetics and Development 10:638-643. 2000.

COHEN, S. Control of whitefly vectors of viruses by colour mulches. In: Harris, K.F. \& Maramorosch, K. (Eds.) Pathogens, Vectors, and Plant Diseases, Approaches to Control. New York. Academic Press.1982. pp. 45-56.

COHEN, S., KERN, J., HARPAZ, I. \& BEN-JOSEPH, R. Epidemiological studies on the tomato yellow leaf curl virus (TYLCV) in the Jordan Valley, Israel. Phytoparasitica 16:259270. 1988. 
COOPER, B., LAPIDOT, M., HEICK, J.A., DODDS, J.A. \& BEACHY, R.N. A defective movement protein of TMV in transgenic plants confers resistance to multiple viruses whereas the functional analog increases susceptibility. Virology 206:307-313. 1995.

COVEY, S.N. \& AL-KAFF, N.S. Plant DNA viruses and gene silencing. Plant Molecular Biology 43:307-322. 2000.

COVEY, S.N., AL-KAFF, N.S., LANGARA, A. \& TURNER, D.S. Plants combat infection by gene silencing. Nature 85:780-781. 1997.

CSIZINSZKY, A.A., SCHUSTER, D.J. \& KRING, J.B. Colour mulches influence yield and insect pest populations in tomatoes. Journal of the American Society for Horticultural Sciences 120:778-784. 1995

CZOSNEK, H. \& LATERROT, H. A world-wide survey of tomato yellow leaf curl viruses. Archives of Virology 142:1391-1406. 1997.

DAY, A.G., BEJARANO, E.R., BUCK, K.W., BURREL, M. \& LICHTENSTEIN, C.P. Expression of an antisense viral gene in transgenic tobacco confers resistance to the DNA virus tomato golden mosaic virus. Proceedings of the National Academy of Sciences of the USA 88:6721-6725. 1991.

DIAZ-PLAZA, R., BONILLA, M., CALDERON, E., RANGEL, R.M. \& BUSTAMANTE-RIVERA, R.F. A point mutation in PHV BL1 protein shows negative dominance and confers resistance in transgenic tobacco. Annals, $3^{\text {rd }}$ International Geminivirus Symposium, Norwich, UK. 2001. p. 93.

DODDS, J.A. Cross-protection and interference between electrophoretically distinct strains of cucumber mosaic virus in tomato. Virology 118:235-240. 1982.

DONSON, J., KEARNEY, C.M., TURPEN, T.H., KHAN, I.A., KURATH, G., TURPEN, A.M., JONES, G.E. \& DAWSON, W.O. Broad resistance to tobamoviruses is mediated by a modified tobacco mosaic virus replicase transgene. Molecular Plant-Microbe Interactions 6:635-642. 1993.

DUAN, Y.P., POWELL, C.A., WEBB, S.E., PURCIFULL, D.E. \& HIEBERT, E. Geminivirus resistance in transgenic tobacco expressing mutated $\mathrm{BC} 1$ protein. Molecular Plant-Microbe Interactions 10:617-623. 1997.

ELBASHIR, S.M., HARBORTH, J., LENDECKEL, W., YALCIN, A., WEBER, K. \& TUSCHL, T. Duplexes of 21-nucleotide RNAs mediate RNA interference in cultured mammalian cells. Nature 411:494-498. 2001.

ENGLISH, J.J., MUELLER, E. \& BAULCOMBE, D.C. Suppression of virus accumulation in transgenic plants exhibiting silencing of nuclear genes. Plant Cell 8:179-188. 1996.

FAGARD, M., BOUTET, S., MOREL, J.-B., BELLINI, C. \& VAUCHERET, H. AGO1, QDE-2, and RDE-1 are related proteins required for post-transcriptional gene silencing in plants, quelling in fungi, and RNA interference in animals. Proceedings of the National Academy of Sciences of the USA 97:11650-11654. 2000.

FARIA, J.C., BEZERRA, I.C., ZERBINI, F.M., RIBEIRO, S.G. \& LIMA, M.F. Situação atual das geminiviroses no Brasil. Fitopatologia Brasileira 25:125-137. 2000.

FARIA, J.C. \& ZERBINI, F.M. Família Geminiviridae - taxonomia, replicação e movimento. Revisão Anual de Patologia de Plantas 8:27-57. 2000

FARIA, M. \& WRAIGHT, S.P. Biological control of Bemisia tabaci with fungi. Crop Protection 20:767-778. 2001.

FAUGERON, G. Diversity of homology-dependent gene silencing strategies in fungi. Current Opinion in Microbiology 3:144148. 2000.

FAUQUET, C.M., MAXWELL, D.P., GRONENBORN, B. \& STANLEY, J. Revised proposal for naming geminiviruses. Archives of Virology 145:1743-1761. 2000.

FERREIRA, P.T.O., BEZERRA, I.C., VILLAS BÔAS, G.L., RIBEIRO, S.G. \& GIORDANO, L.B. Avaliação de fontes de resistência a isolado de geminivírus com genoma bipartido transmitido por Bemisia argentifolii em Lycopersicon spp. Fitopatologia Brasileira 24:131-135. 1999.

FIRE, A., XU, S., MONTGOMERY, M.K., KOSTAS, S.A., DRIVER, S.E. \& MELLO, C.C. Potent and specific genetic interference by double-stranded RNA in Caenorhabditis elegans. Nature 391:806-811. 1998.

FRANCO, M., MORILLA, G. \& BEJARANO, E. Resistance to the geminivirus TYLCV by a double mechanism involving antisense RNA and extrachromosomal molecules. Annals, $3^{\text {rd }}$ International Geminivirus Symposium, Norwich, UK. 2001. p. 69.

FREITAS-ASTÚA, J. Characterization of resistance in transgenic tobacco plants expressing begomoviruses genes. (PhD Dissertation). Gainesville. University of Florida. 2001.

FREITAS-ASTÚA, J., POLSTON, J.E. \& HIEBERT, E. Further characterization of the resistance in tobacco lines expressing the Tomato mottle virus $\mathrm{BCl}$ movement protein gene. Annals, $3^{\text {rd }}$ International Geminivirus Symposium, Norwich, UK. 2001a. p 33.

FREITAS-ASTÚA, J., YANG, Y., POLSTON, J.E. \& HIEBERT, E. Obtenção de plantas transgênicas de fumo resistentes aos begomovirus ToMoV e TYLCV. Fitopatologia Brasileira 26:536. 2001b.

GÁLVEZ, G.E. \& CASTAÑO, M.J. Purification of the whiteflytransmitted bean golden mosaic virus. Turrialba 26:205-207. 1976.

GERLING, D., ALOMAR, O. \& ARNÓ, J. Biological control of Bemisia tabaci using predators and parasitoids. Crop Protection 20:779-799. 2001.

GOODMAN, R.M. Single stranded-DNA genome in a whiteflytransmitted plant virus. Virology 83:171-179. 1977a.

GOODMAN, R.M. A new kind of virus is discovered. Illinois Research 19:5. 1977b.

GOREGAOKER, S.P., ECKHARDT, L.G. \& CULVER, J.N. Tobacco mosaic virus replicase-mediated cross-protection: Contributions of RNA and protein-derived mechanisms. Virology 273:267-275. 2000.

GRISHOK, A., PASQUINELLI, A.E., CONTE, D., LI, N., PARRISH, S., HA, I., BAILLIE, D.L., FIRE, A., RUVKUN, G. \& MELLO, C.C. Genes and mechanisms related to RNA interference regulate expression of the small temporal RNAs that control C. elegans developmental timing. Cell 106:23-34. 2001.

GUTIERREZ, C. The retinoblastoma pathway in plant cell cycle and development. Current Opinion in Plant Biology 1:492497. 1998.

GUTIERREZ, C. Geminivirus DNA replication. Cellular and Molecular Life Sciences 56:313-329. 1999.

GUTIERREZ, C. Geminiviruses and the plant cell cycle. Plant Molecular Biology 43:763-772. 2000.

HAMMOND, S.M., BOETTCHER, S., CAUDY, A.A., KOBAYASHI, R. \& HANNON, G.J. Argonaute2, a link between genetic and biochemical analyses of RNAi. Science 
293:1146-1150. 2001a.

HAMMOND, S.M., CAUDY, A.A. \& HANNON, G.J. Posttranscriptional gene silencing by double-stranded RNA. Nature Reviews in Genetics 2:110-119. $2001 \mathrm{~b}$.

HANLEY-BOWDOIN, L., SETTLAGE, S.B., OROZCO, B.M., NAGAR, S. \& ROBERTSON, D. Geminiviruses: models for plant DNA replication, transcription, and cell cycle regulation. Critical Reviews in Plant Sciences 18:71-106. 1999.

HANSON, S.F., HOOGSTRATEN, R.A., AHLQUist, P., GILBERTSON, R.J., RUSSELL, D.R. \& MAXWELL, D.P. Mutational analysis of a putative ntp-binding domain in the replication-associated protein $(\mathrm{AC} 1)$ of bean golden mosaic geminivirus. Virology 211:1-9. 1995.

HARPER, G., HULL, R., LOCKHART, B. \& OLSZEWSKI, N. Viral sequences integrated into plant genomes. Annual Review of Phytopathology 40:119-136. 2002.

HARRISON, B.D., BAKER, H., BOCK, K.R., GUTHRIE, E.J., MEREDITH, G. \& ATKINSON, M. Plant viruses with circular single-stranded DNA. Nature 270:760-762. 1977.

HARRISON, B.D. \& ROBINSON, D.J. Natural genomic and antigenic variation in whitefly-transmitted geminiviruses (begomoviruses). Annual Review of Phytopathology 37:369398. 1999.

HAYES, R.J., PETTY, I.T.D., COUTTS, H.A. \& BUCK, K.W. Gene amplification and expression in plants by a replicating geminivirus vector. Nature 334:179-182. 1988.

HERSKOWITZ, I. Functional inactivation of genes by dominant negative mutations. Nature 329:219-222. 1987.

HILJE, L., COSTA, H.S. \& STANSLY, P.A. Cultural practices for managing Bemisia tabaci and associated viral diseases. Crop Protection 20:801-812. 2001.

HONG, Y., SAUNDERS, K., HARTLEY, M.R. \& STANLEY, J. Resistance to geminivirus infection by virus-induced expression of dianthin in transgenic plants. Virology 220:119127. 1996.

HONG, Y. \& STANLEY, J. Virus resistance in Nicotiana benthamiana conferred by African cassava mosaic virus replication-associated protein (AC1) transgene. Molecular Plant-Microbe Interactions 9:219-225. 1996.

HOU, Y.M., SANDERS, R., URSIN, V.M. \& GILBERTSON, R.L. Transgenic plants expressing geminivirus movement proteins: Abnormal phenotypes and delayed infection by Tomato mottle virus in transgenic tomatoes expressing Bean dwarf mosaic virus $\mathrm{BV} 1$ or $\mathrm{BC} 1$ proteins. Molecular Plant-Microbe Interactions 13:297-308. 2000.

HUTVÁGNER, G., McLACHLAN, J., PASQUINELLI, A.E., BÁLINT, E., TUSCHL, T. \& ZAMORE, P.D. A cellular function for the RNA-interference enzyme Dicer in the maturation of the let-7 small temporal RNA. Science 293:834838. 2001.

HUTVÁGNER, G., MLYNÁROVÁ, L. \& NAP, J.-P. Detailed characterization of the posttranscriptional gene-silencingrelated small RNA in a GUS gene-silenced tobacco. RNA 6:1445-1454. 2000.

HUTVÁGNER, G. \& ZAMORE, P.D. RNAi: nature abhors a doublestrand. Current Opinion in Genetics and Development 12:225232. 2002.

KASRAWI, M.A., SUWWAN, M.A. \& MANSOUR, A. Sources of resistance to tomato yellow leaf curl virus in Lycopersicon species. Euphytica 37:61-64. 1988.

KASSCHAU, K.D. \& CARRINGTON, J.C. A counter-defensive strategy of plant viruses: suppression of post-transcriptional gene silencing. Cell 95:461-470. 1998.

KETTING, R.F. \& PLASTERK, R.H.A. A genetic link between cosuppression and RNA interference in C. elegans. Nature 404:296-298. 2000.

KJEMTRUP, S., SAMPSON, K.S., PEELE, C.G., NGUYEN, L.V., CONKLING, M.A., THOMPSON, W.F. \& ROBERTSON, D. Gene silencing from plant DNA carried by a geminivirus. Plant Journal 14:91-100. 1998.

KONG, J.L., OROZCO, B.M., ROE, J.L., NAGAR, S., MILLER, A.B., GRUISSEM, W., ROBERTSON, D. \& HANLEYBOWDOIN, L. A geminivirus replication protein interacts with the retinoblastoma protein through a novel domain to determine symptoms and tissue specificity of infection in plants. EMBO Journal 19:3485-3495. 2000.

KUNIK, T., SALOMON, R., ZAMIR, D., NAVOT, N., ZEIDAN, M., MICHELSON, I., GAFNI, Y. \& CZOSNEK, H. Transgenic tomato plants expressing the tomato yellow leaf curl virus capsid protein are resistant to the virus. Bio/Technology 12:500504. 1994.

LAPIDOT, M., FRIEDMANN, M., LACHMAN, O., ANTIGNUS, Y., NAHON, S., COHEN, S. \& PILOWSKY, M. Comparison of resistance level to tomato yellow leaf curl virus among commercial cultivars and breeding lines. Plant Disease 81:1425-1428. 1997.

LAPIDOT, M., FRIEDMANN, M., PILOWSKY, M., BEN-JOSEPH, R. \& COHEN, S. Effect of host plant resistance to Tomato yellow leaf curl virus (TYLCV) on virus acquisition and transmission by its whitefly vector. Phytopathology 91:12091213. 2001

LAPIDOT, M., GAFNY, R., DING, B., WOLF, S., LUCAS, W.J. \& BEACHY, R.N. A dysfunctional movement protein of tobacco mosaic virus that partially modifies the plasmodesmata and limits virus spread in transgenic plants. Plant Journal 4:959970. 1993.

LAZAROWITZ, S.G. Probing plant cell structure and function with viral movement proteins. Current Opinion in Plant Biology 2:332-338. 1999.

LI, W.X. \& DING, S.W. Viral suppressors of RNA silencing. Current Opinion in Biotechnology 12:150-154. 2001.

LINDBO, J.A. \& DOUGHERTY, W.G. Untranslatable transcripts of the tobacco etch virus coat protein gene sequence can interfere with tobacco etch virus replication in transgenic plants and protoplasts. Virology 189:725-733. 1992a.

LINDBO, J.A. \& DOUGHERTY, W.G. Pathogen-derived resistance to a potyvirus: immune and resistant phenotypes in transgenic tobacco expressing altered forms of a potyvirus coat protein nucleotide sequence. Molecular Plant-Microbe Interactions 5:144-153. 1992b.

LINDBO, J.A., SILVA-ROSALES, L., PROEBSTING, W.M. \& DOUGHERTY, W.G. Induction of a highly specific antiviral state in transgenic plants:implications for regulation of gene expression and virus resistance. Plant Cell 5:1749-1759. 1993.

LIU, T.-X. \& STANSLY, P.A. Insecticidal activity of surfactants and oils against silverleaf whitefly (Bemisia argentifolii) nymphs (Homoptera: Aleyrodidae) on collards and tomato. Pest Management Science 56:861-866. 2000.

LOHMANN, J.U., ENDL, I. \& BOSCH, T.C. Silencing of developmental genes in Hydra. Developmental Biology 214:211-214. 1999.

LOMONOSSOFF, G.P. Pathogen-derived resistance to plant viruses. 
Traditional and transgenic strategies for controlling tomato-infecting begomoviruses

Annual Review of Phytopathology 33:323-343. 1995.

MARANO, M.R. \& BAULCOMBE, D.C. Pathogen-derived resistance targeted against the negative-strand RNA of tobacco mosaic virus. Plant Journal 13:537-546. 1998.

MARATHE, R., ANANDALAKSHMI, R., SMITH, T.H., PRUSS, G.J. \& VANCE, V.B. RNA viruses as inducers, suppressors and targets of post-transcriptional gene silencing. Plant Molecular Biology 43:295-306. 2000.

MASON, G., RANCATI, M. \& BOSCO, D. The effect of thiamethoxam, a second generation neonicotinoid insecticide, in preventing transmission of tomato yellow leaf curl geminivirus (TYLCV) by the whitefly Bemisia tabaci (Gennadius). Crop Protection 19:473-479. 2000.

MEHTA, P., WYMAN, J.A., NAKHLA, M.K. \& MAXWELL, D.P. Transmission of tomato yellow leaf curl geminivirus by Bemisia tabaci (Homoptera: Aleyrodidae). Journal of Economic Entomology 87:1291-1297. 1994.

METTE, M.F., KANNO, T., AUFSATZ, W., JAKOWITSCH, J., VAN DER WINDEN, J., MATZKE, M.A. \& MATZKE, A.J.M. Endogenous viral sequences and their potential contribution to heritable virus resistance in plants. The EMBO Journal 21:461-469. 2002.

METZLAFF, M., O’DELL, M., CLUSTER, P.D. \& FLAVELL, R.B. RNA-mediated RNA degradation and chalcone synthase A silencing in petunia. Cell 88:845-854. 1997.

MICHELSON, I., ZAMIR, D. \& CZOSNEK, H. Accumulation and translocation of tomato yellow leaf curl virus (TYLCV) in a Lycopersicon esculentum breeding line containing the $L$. chilense TYLCV tolerance gene Ty-1. Phytopathology 84:928933. 1994.

MILLER, W.A., WATERHOUSE, P.M., BROWN, J.W.S. \& BROWNING, K.S. The RNA world in plants: Posttranscriptional control III. Plant Cell 13:1710-1717. 2001.

MORALES, F.J. Conventional breeding for resistance to Bemisia tabaci-transmitted geminiviruses. Crop Protection 20:825-834. 2001.

MORALES, F.J. \& ANDERSON, P.K. The emergence and dissemination of whitefly-transmitted geminiviruses in Latin America. Archives of Virology 146:415-441. 2001.

MORIONES, E. \& NAVAS-CASTILLO, J. Tomato yellow leaf curl virus, an emerging virus complex causing epidemics worldwide. Virus Research 71:123-134. 2000.

NAPOLI, D., LEMIEUX, C. \& JORGENSEN, R. Introduction of a chimeric chalcone synthase gene into petunia results in cosuppression of homologous genes in trans. Plant Cell 2:279289. 1990.

NAVAS-CASTILLO, J., SÁNCHEZ-CAMPOS, S., NORIS, E., LOURO, D., ACCOTTO, G.P. \& MORIONES, E. Natural recombination between Tomato yellow leaf curl virus-Is and Tomato leaf curl virus. Journal of General Virology 81: 27972801. 2000.

NEJIDAT, A. \& BEACHY, R.N. Decreased levels of TMV coat protein in transgenic tobacco plants at elevated temperatures reduce resistance to TMV infection. Virology 173:531-538. 1989.

NGO, H., TSCHUDI, C., GULL, K. \& ULLU, E. Double-stranded RNA induces mRNA degradation in Trypanosoma brucei. Proceedings of the National Academy of Sciences of the USA 95:15502-15507. 1998.

NORIS, E., ACCOTTO, G.P., TAVAZZA, R., BRUNETTI, A., CRESPI, S. \& TAVAZZA, M. Resistance to tomato yellow leaf curl geminivirus in Nicotiana benthamiana plants transformed with a truncated viral C1 gene. Virology 224:130138. 1996.

NOUEIRY, A.O., LUCAS, W.J. \& GILBERTSON, R.L. Two proteins of a plant DNA virus coordinate nuclear and plasmodesmal transport. Cell 76:925-932. 1994.

PALMER, K.E. \& RYBICKI, E.P. The molecular biology of Mastreviruses. Advances in Virus Research 50:183-234. 1998.

PANG, S.-Z., BOCK, J.H., GONSALVES, C., SLIGHTOM, J.L. \& GONSALVES, D. Resistance of transgenic Nicotiana benthamiana plants to tomato spotted wilt and impatiens necrotic spot tospoviruses: evidence of involvement of the $\mathrm{N}$ protein and $N$ gene RNA in resistance. Phytopathology 84:243249. 1994.

PAPPU, H.R., NIBLETT, C.L. \& LEE, R.F. Application of recombinant DNA technology to plant protection: molecular approaches to engineering virus resistance in crop plants. World Journal of Microbiology and Biotechnology 11:426-437. 1995.

PICÓ, B., DÍEZ, M.J. \& NUEZ, F. Evaluation of whitefly-mediated inoculation techniques to screen Lycopersicon esculentum and wild relatives for resistance to Tomato yellow leaf curl virus. Euphytica 101:259-271. 1998.

PIVEN, N.M. \& UZCÁTEGUI, R. Resistance to mosaic virus in species of Lycopersicon. Plant Disease 79:590-594. 1995.

POLSTON, J.E. \& ANDERSON, P.K. The emergence of whiteflytransmitted geminiviruses in tomato in the Western Hemisphere. Plant Disease 81:1358-1369. 1997.

POLSTON, J.E., YANG, Y., SHERWOOD, T.A., BUCHER, C., FREITAS-ASTÚA, J. \& HIEBERT, E. Effective resistance to Tomato yellow leaf curl virus in tomato mediated by a truncated viral Rep gene. Annals, $3^{\text {rd }}$ International Geminivirus Symposium, Norwich, UK. 2001. p. 82.

POWELL-ABEL, P., NELSON, R.S., DE, B., HOFFMANN, N., ROGERS, S.G., FRALEY, R.T. \& BEACHY, R.N. Delay of disease development in transgenic plants that express the tobacco mosaic virus coat protein gene. Science 232:738-743. 1986.

PRINS, M. \& GOLDBACH, R. RNA-mediated virus resistance in transgenic plants. Archives of Virology 141:2259-2276. 1996.

PRINS, M., KIKKERT, M., ISMAYADI, C., GRAAUW, W. DE., HAAN, P. DE. \& GOLDBACH, R. Characterization of RNAmediated resistance to tomato spotted wilt virus in transgenic tobacco plants expressing NS (M) gene sequences. Plant Molecular Biology 33:235-243. 1997.

RAFIE, A., DÍAZ, J. \& MCLEOD, P. Effects of forage groundnut in reducing the sweetpotato whitefly and associated Gemini virus disease in bell pepper in Honduras. Tropical Agriculture 76:208-211. 1999.

RATCLIFF, F., HARRISON, B.D. \& BAULCOMBE, D.C. A similarity between viral defense and gene silencing in plants. Science 276:1558-1560. 1997.

REGISTER III, J.C. \& BEACHY, R.N. Resistance to TMV in transgenic plants results from interference with an early event in infection. Virology 166:524-532. 1988.

RIBEIRO, S.G., AMBROZEVÍCIUS, L.P., DEÁVILA, A.C., CALEGARIO, R.F., FERNANDES, J.J., LIMA, M.F., DE MELLO, R.N., ROCHA, H. \& ZERBINI, F.M. Distribution and genetic diversity of tomato-infecting geminiviruses in Brazil. Annals, $3^{\text {rd }}$ International Geminivirus Symposium, Norwich, UK. 2001. p. 116.

RIBEIRO, S.G., LACORTE, C., INOUE-NAGATA, A.K., CARMO, 


\section{J. Freitas-Astúa et al.}

I., ORLANDINI, D., NAGATA, T. \& ZERBINI, F.M. Tomato chlorotic mottle virus: A novel tomato begomovirus from Brazil. Fitopatologia Brasileira 27:S211. 2002. (Abstract)

ROJAS, M.R., NOUEIRY, A.O., LUCAS, W.J. \& GILBERTSON, R.L. Bean dwarf mosaic geminivirus movement proteins recognize DNA in a form- and size-specific manner. Cell 95:105-113. 1998.

ROM, M., ANTIGNUS, Y., GIDONI, D., PILOWSKY, M. \& COHEN, S. Accumulation of tomato yellow leaf curl virus DNA in tolerant and susceptible tomato lines. Plant Disease 77:253-257. 1993

RYBICKI, E.P. A phylogenetic and evolutionary justification for three genera of Geminiviridae. Archives of Virology 139:4977. 1994.

RYBICKI, E.P., BRIDDON, R.W., BROWN, J.K., FAUQUET, C.M., MAXWELL, D.P., HARRISON, B.D., MARKHAM, P.G., BISARO, D.M., ROBINSON, D. \& STANLEY, J. Family Geminiviridae. In: Van Regenmortel, M.H.V., Bishop, D.H.L., Carstens, E.B., Estes, M.K., Lemon, S.M., Maniloff, J., Mayo, M.A., McGeoch, D.J., Pringle, C.R. \& Wickner, R.B. (Eds.) Virus Taxonomy:Classification and Nomenclature of Viruses, Seventh report of the International Committee on Taxonomy of Viruses. Ed. by Wickner. Academic Press, San Diego, CA. 2000. pp.285-297.

SALATI, R., NAHKLA, M.K., MAXWELL, D.P. \& GILBERTSON, R.L. Molecular epidemiology of tomato yellow leaf curl virus in the Dominican Republic: Identification of inoculum sources during a host-free period. Phytopathology 89:S68. 1999 (Abstract)

SÁNCHEZ-ALVARADO, A. \& NEWMARK, P.A. Double-stranded RNA specificity disrupts gene expression during planarian regeneration. Proceedings of the National Academy of Sciences of the USA 96:5049-5054. 1999.

SANDERFOOT, A.A., INGHAM, D.L. \& LAZAROWITZ, S.G. A viral movement protein as a nuclear shuttle. The geminivirus BR1 movement protein contains domains essential for interaction with BL1 and nuclear localization. Plant Physiology 110:23-33. 1996.

SANDERFOOT, A.A. \& LAZAROWITZ, S.G. Cooperation in viral movement: The geminivirus BL1 movement protein interacts with BR1 and redirects it from the nucleus to the cell periphery. Plant Cell 7:1185-1194. 1995.

SANDERFOOT, A.A. \& LAZAROWITZ, S.G. Getting it together in plant virus movement: cooperative interactions between bipartite geminivirus movement proteins. Trends in Cell Biology 6:353-358. 1996.

SANFORD, J.C. \& JOHNSON, S.A. The concept of parasite-derived resistance: deriving resistance genes from the parasites own genome. Journal of Theoretical Biology 115:395-405. 1985.

SANTANA, F.M., RIBEIRO, S.G., MOITA, A.W., MOREIRA JR., D.J. \& GIORDANO, L.B. Sources of resistance in Lycopersicon spp. to a bipartite whitefly-transmitted geminivirus from Brazil. Euphytica 122:45-51. 2001.

SAUNDERS, K., BEDFORD, I. D., BRIDDON, R. W., MARKHAM, P. G., WONG, S. M. \& STANLEY, J. A unique virus complex causes Ageratum yellow vein disease. Proceedings of the National Academy of Sciences of the USA 97:6890-6895. 2000.

SAUNDERS, K., BEDFORD, I.D. \& STANLEY, J. Pathogenicity of a natural recombinant associated with Ageratum yellow vein disease: Implications for geminivirus evolution and disease aetiology. Virology 282: 38-47. 2001.

SETTLAGE, S.B., MILLER, A.B., GRUISSEM, W. \& HANLEYBOWDOIN, L. Dual interaction of a geminivirus replication accessory factor with a viral replication protein and a plant cell cycle regulator. Virology 279:570-576. 2001.

SHEN, W.H. \& HOHN, B. Vectors based on maize streak virus can replicate to high copy numbers in maize plants. Journal of General Virology 76:965-969. 1995.

SHERWOOD, J.L. \& FULTON, R.W. The specific involvement of coat protein in tobacco mosaic virus (TMV) cross protection. Virology 119:150-158. 1982.

SIJEN, T., WELLINK, J., HENDRIKS, J., VERVER, J. \& KAMMEN, A. VAN. Replication of cowpea mosaic virus RNA1 or RNA2 is specifically blocked in transgenic Nicotiana benthamiana plants expressing the full-length replicase or movement protein genes. Molecular Plant-Microbe Interactions 8:340-347. 1995.

SIJEN, T., WELLINK, J., HIRIART, J.B. \& KAMMEN, A. VAN. RNA-mediated virus resistance:role of repeated transgenes and delineation to targeted regions. Plant Cell 8:2277-2294. 1996.

SINISTERRA, X.H., POLSTON, J.E., ABOUZID, A.M. \& HIEBERT, E. Tobacco plants transformed with a modified coat protein of tomato mottle begomovirus show resistance to virus infection. Phytopathology 89:701-706. 1999.

SMYTH, D.R. Gene silencing: plants and viruses fight it out. Current Biology 9:R100-R102. 1999.

STOUT, J.T., LIU, H.T., POLSTON, J.E., GILBERTSON, R.L., NAKHLA, M.K., HANSON, S.F. \& MAXWELL, D.P. Engineered rep gene-mediated resistance to tomato mottle geminivirus in tomato. Phytopathology 87:S94. 1997 (Abstract).

SUWWAN, M.A., AKKAWI, M., AL-MUSA, A.M., MANSOUR, A. Tomato performance and incidence of tomato yellow leaf curl (TYLC) virus as affected by type of mulch. Scientia Horticulturae 37:39-45. 1988.

TAYLOR, R.A.J., SHALHEVET, S., SPHARIM, I., BERLINGER, M.J. \& LEBIUSH-MORDECHI, S. Economic evaluation of insect-proof screens for preventing tomato yellow leaf curl virus of tomatoes in Israel. Crop Protection 20:561-569. 2001.

TENLLADO, F., GARCIA-LUQUE, I., SERRA, M.T. \& DIAZRUIZ, J.R. Resistance to pepper mild mottle tobamovirus conferred by the 54-kDa gene sequence in transgenic plants does not require expression of the wild-type $54-\mathrm{kDa}$ protein. Virology 219:330-335. 1996.

UCKO, O.S., COHEN, S., BEN-JOSEPH, R. Prevention of virus epidemics by a crop-free period in the Arava region of Israel. Phytoparasitica 26:313-321. 1998.

VAN DER KROL, A.R., MUR, L.A., BELD, M., MOL, J.L. \& STUITJE, A.R. Flavonoid genes in petunia: addition of a limited number of gene copies may lead to a suppression of gene expression. Plant Cell 2:291-299. 1990.

VAN DER VLUGT, R.A.A., RUITER, R.K. \& GOLDBACH, R. Evidence for sense RNA-mediated resistance to $\mathrm{PVY}^{\mathrm{N}}$ in tobacco plants transformed with the viral coat protein cistron. Plant Molecular Biology 20:631-639. 1992.

VIDAVSKY, F. \& CZOSNEK, H. Tomato breeding lines resistant and tolerant to tomato yellow leaf curl virus issued from Lycopersicon hirsutum. Phytopathology 88:910-914. 1998.

VILLAS BÔAS, G.L., FRANÇA, F.H., ÁVILA, A.C. \& BEZERRA, I.C. Manejo integrado da mosca-branca Bemisia argentifolii. Circular técnica da Embrapa Hortaliças, nº. 11pp. 1997.

WARD, B.M. \& LAZAROWITZ, S.G. Nuclear export in plants: 
use of geminivirus movement proteins for a cell-based export assay. Plant Cell 11:1267-1276. 1999.

WARGELIUS, A., ELLINGSEN, S. \& FJOSE, A. Double-stranded RNA induces specific developmental defects in zebrafish embryos. Biochemical and Biophysical Research Communications 263:156-161. 1999.

WASSENEGGER, M. \& PÉLISSIER, T. A model for RNA-mediated gene silencing in higher plants. Plant Molecular Biology 37:349-362. 1998 .

WATERHOUSE, P.M., GRAHAM, M.W. \& WANG, M.-B. Virus resistance and gene silencing in plants can be induced by simultaneous expression of sense and antisense RNA. Proceedings of the National Academy of Sciences of the USA 95:13959-13964. 1998.

WATERHOUSE, P.M., WANG, M.B. \& LOUGH, T. Gene silencing as an adaptive defence against viruses. Nature 411:834-842. 2001.

WEGE, C., GOTTHARDT, R.D., FRISCHMUTH, T. \& JESKE, H. Fulfilling Koch's postulates for Abutilon mosaic virus. Archives of Virology 145:2217-2225. 2000.

WIANNY, F. \& ZERNICKA-GOETZ, M. Specific interference with gene function by double-stranded RNA in early mouse development. Natural Cell Biology 2:70-75. 2000.
WINTERMANTEL, W.M. \& ZAITLIN, M. Transgene translatability increases effectiveness of replicase-mediated resistance to Cucumber mosaic virus. Journal of General Virology 81:587595. 2000.

ZAKAY, Y., NAVOT, N., ZEIDAN, M., KEDAR, N., RABINOWITCH, H., CZOSNEK, H. \& ZAMIR, D. Screening Lycopersicon accessions for resistance to tomato yellow leaf curl virus: presence of viral DNA and symptom development. Plant Disease 75:279-281. 1991.

ZAMORE, P.D. Ancient pathways programmed by small RNAs. Science 296:1265-1269. 2002.

ZAMORE, P.D., TUSCHI, T., SHARP, P.A. \& BARTEL, D.P. RNAi: Double-stranded RNA directs the ATP-dependent cleavage of mRNA at 21 to 23 nucleotide intervals. Cell 101:25-33. 2000.

ZHOU, X., LIU, Y., CALVERT, L., MUNOZ, C., OTIM-NAPE, G.W., ROBINSON, D.J. \& HARRISON, B.D. Evidence that DNA-A of a geminivirus associated with severe cassava mosaic disease in Uganda has arisen by interspecific recombination. Journal of General Virology 78:2101-2111. 1997.

ZIEGLER-GRAFF, V., GUILFORD, P.J. \& BAULCOMBE, D.C. Tobacco rattle virus RNA-1 29K gene product potentiates viral movement and also affects symptom induction in tobacco. Virology 182:145-155. 1991. 